\title{
Low-dose insulin-like growth factor binding proteins 1 and 2 and angiopoietin-like protein 3 coordinately stimulate ex vivo expansion of human umbilical cord blood hematopoietic stem cells as assayed in NOD/SCID gamma null mice
}

Xiubo Fan' ${ }^{1}$, Florence PH Gay², Francesca WI Lim³ ${ }^{3}$ Justina ML Ang ${ }^{2}$, Pat PY Chu ${ }^{3}$, Sudipto Bari ${ }^{3}$ and William YK Hwang ${ }^{2,3^{*}}$

\begin{abstract}
Introduction: Insulin-like growth factors (IGFs), IGF binding proteins (IGFBPs) and angiopoietin-like proteins (ANGPTLs) can enhance the ex vivo expansion of hematopoietic stem cells (HSCs) when used with a standard cytokine cocktail of stem cell factor (SCF), thrombopoietin (TPO) and FLT3 ligand (FL). In order to determine the optimal dose and combination of IGFs, IGFBPs and ANGPTLs, serial dilution and full permutation of IGFBP1, IGFBP2, IGF2 and ANGPTL3 were applied on a cryopreserved umbilical cord blood mononuclear cell (UCB-MNC) ex vivo expansion system.
\end{abstract}

Methods: In this system, $4 \times 10^{5}$ cells/ml of UCB-MNCs were inoculated in serum-free Stemspan ${ }^{\oplus}$ medium (Stemcell technologies, vancouver, BC, Canada) supplied with standard basal cytokine combination of $100 \mathrm{ng} / \mathrm{ml} \mathrm{SCF}, 50 \mathrm{ng} /$ $\mathrm{ml} \mathrm{FL}$ and $100 \mathrm{ng} / \mathrm{ml} \mathrm{TPO}$ and supported by a bone marrow mesenchymal stromal cell layer.

Results: Paradoxically, experiment results showed that the highest expansion of $\mathrm{CD} 34^{+} \mathrm{CD} 38^{-} \mathrm{CD} 90^{+}$primitive progenitor was stimulated by cytokine combination of SCF + TPO + FL + IGFBP1 + IGFBP2 + ANGPTL3 at a low dose of $15 \mathrm{ng} / \mathrm{ml}$ IGFBP1 and $20 \mathrm{ng} / \mathrm{ml}$ IGFBP2 and ANGPTL3. This ex vivo expansion was further validated in 8-week-old to 10-week-old nonobese diabetic/severe combined immunodeficiency interleukin 2 gamma chain null (NOD/ SCID-IL2RY ${ }^{-1-}$ ) mice. Limiting dilution assay showed excellent correlation between the HSC ex vivo surface marker of $\mathrm{CD}_{4}{ }^{+} \mathrm{CD} 38^{-} \mathrm{CD} 90^{+}$and the in vivo competitive repopulating unit (CRU) functional assay.

Conclusion: IGFBP1, IGFBP2, IGF2 and ANGPTL3 can stimulate the expansion of $\mathrm{CD} 34^{+} \mathrm{CD} 38^{-} \mathrm{CD} 90^{+}$primitive progenitor at low dose. The optimal combination comprises IGFBP1, IGFBP2 and ANGPTL3 together with the standard cytokine cocktail of SCF, FL and TPO. The $\mathrm{CD} 34^{+} \mathrm{CD} 38^{-} \mathrm{CD} 90^{+}$phenotype can serve as a surrogate ex vivo surface marker for HSCs due to consistency with the in vivo CRU functional assay.

\footnotetext{
* Correspondence: william.hwang.y.k@sgh.com.sg

${ }^{2}$ Cancer \& Stem Cell Biology, Duke-NUS Graduate Medical School, College Road, Singapore 169857, Singapore

${ }^{3}$ Department of Hematology, Singapore General Hospital, 20 College Road, Academia Level 3, Singapore 169856, Singapore

Full list of author information is available at the end of the article
} 


\section{Introduction}

Ex vivo expansion of umbilical cord blood (UCB) hematopoietic stem cells (HSCs) may overcome the obstacle of low cell dose for UCB transplantation in adults. Insulin-like growth factors (IGFs), insulin-like growth factor binding proteins (IGFBPs) and angiopoietin-like proteins (ANGPTLs) have been described previously to help enhance ex vivo expansion of HSCs when used with a standard cytokine cocktail of stem cell factor (SCF), thrombopoietin (TPO) and FLT3 ligand (FL) [1-10]. ANGPTLs and IGFBPs have also been demonstrated to enhance HSC in vivo migration and activity, supporting survival and replating capacity [11-14]. However, the optimal dose and combination of these novel cytokines have yet to be determined. Current doses of IGFBPs and ANGPTLs are in the range of 100 to $500 \mathrm{ng} / \mathrm{ml}$. In terms of clinical application, these concentrations may not be optimal and would be costly. Hence, investigations into the optimal cytokine dose and combination of IGFs, IGFBPs and ANGPTLs are important.

In this study, serial dilution and full permutation were used to determine the optimal cytokine dose and combination for stimulation of ex vivo expansion of UCB-HSCs. This established cytokine dose and combination were then further validated in 8-week-old to 10-week-old nonobese diabetic/ severe combined immunodeficiency interleukin 2 receptor gamma chain null (NOD/SCID-IL2R ${ }^{-1-}$; NSG) mice.

\section{Methods}

\section{Cell preparation}

Cryopreserved UCB was obtained from Singapore Cord Blood Bank. Bone marrow (BM) was obtained from Singapore General Hospital with the donor's informed consent. The use of UCB and BM was reviewed and approved by the Institutional Review Boards of National University of Singapore, Singapore General Hospital as well as the Singapore Cord Blood Bank Research Advisory Ethics Committee (for UCB). Cryopreserved UCB was processed in Singapore Cord Blood Bank following the standard volume reduction and red blood cell depletion method. The characteristics of the UCBs employed in this study are summarized in Table 1. BM-derived mesenchymal stromal cell culture was obtained as described in our previous publication $[15,16]$.

\section{Cell culture}

Cryopreserved UCB mononuclear cells $\left(4 \times 10^{5}\right.$ cells $\left./ \mathrm{ml}\right)$ were suspended in serum-free Stemspan ${ }^{\circ}$ medium (Stemcell technologies, vancouver, BC, Canada) supplied with a standard cytokine combination of $100 \mathrm{ng} / \mathrm{ml} \mathrm{SCF}, 50 \mathrm{ng} /$ $\mathrm{ml} \mathrm{FL}$ and $100 \mathrm{ng} / \mathrm{ml}$ TPO (all three cytokines purchased from Peprotech, Rocky Hill, NJ, USA) and with individually varied doses and combinations of IGFBP1, IGFBP2, IGF2 and ANGPTL3 (these four cytokines purchased from R\&D Systems, Minnneapolis, MN, USA). The cells
Table 1 Cord blood unit phonotype information

\begin{tabular}{lcc}
\hline Unit used in experiment & CD34 $^{+}$cells (\%) & $\begin{array}{c}\text { CD34 }{ }^{+} \text {CD38 } \mathbf{C D}^{+} \\
\text {cells (\%) }\end{array}$ \\
\hline Figure 1 & 2.6 & 0.10 \\
Figure 2 & 1.3 & 0.06 \\
Figure 3 & 1.6 & 0.10 \\
& 0.9 & 0.05 \\
& 1.6 & 0.06 \\
& 0.8 & 0.03 \\
Figures 4 and 5 & 1.7 & 0.07 \\
\hline
\end{tabular}

were inoculated on a passage 3 to 5 BM-derived mesenchymal stromal cell layer and cultured in $37^{\circ} \mathrm{C}$ incubator for 12 days. The expanded cells were harvested at the end of 12 days and the adherent cord blood cells were detached after 1 minute of incubation at room temperature with $0.25 \%$ trypsin-ethylenediamine tetraacetic acid.

\section{Flow cytometric analysis}

All data were acquired using the cytomics FC500 flow cytometer (Beckman Coulter, Inc., Miami, FL, USA) and 10,000 events per sample were collected. Cell viability (AnnV/7AAD), hematopoietic primitive progenitors (CD34/ CD38/CD90) of unexpanded and ex vivo expanded UCB and human cell multi-lineage reconstitution (CD45, CD34, CD71, CD15/66b, CD3 and CD19/20) in mice were analyzed using the same method mentioned in our previously published paper $[15,16]$.

\section{Methylcellulose colony assays}

Quantification of granulocyte-macrophage colony-forming units was performed before and after expansion. The method was similar to our previous publication $[15,16]$.

\section{NOD/SCID-IL2R ${ }^{-/-}$mice transplantation}

NSG mice were purchased from Jackson Laboratories (Klaine, USA) by SingHealth Experimental Medicine Centre and were maintained in the same facility. All animal experiments were performed under the approval of the SingHealth Institutional Animal Care and Use Committee. The unexpanded and expanded UCB with four different cytokine combinations, 'SCF + TPO + FL', 'SCF + TPO + FL + IGFBP2', 'SCF + TPO + FL + IGFBP2 + IGF2 + ANGPTL3' and 'SCF + TPO + F + IGFBP1 + IGF2 + ANGPTL3' at doses of $20 \mathrm{ng} / \mathrm{ml}$ IGFBP2 and ANGPTL3, $15 \mathrm{ng} / \mathrm{ml}$ IGFBP1 and $10 \mathrm{ng} / \mathrm{ml}$ IGF2, were injected intravenously via the tail vein into sublethally irradiated (240 cGy) 8-week-old to 10-week-old NSG mice. Acidified water and cyclosporine A were administered to NSG mice orally and by 
intraperitoneal injection for prophylaxis of bacterial and fungal infection and graft versus host disease.

\section{Harvesting of mouse bone marrow}

At the end of the fourth month of transplantation, the mice were sacrificed using a carbon dioxide chamber. The femur and tibia were harvested and placed into cold RPMI medium (Invitrogen, Grand Island, NY, USA) immediately. Joint ends were cut and BM was flushed out with $10 \mathrm{ml}$ of $2 \%$ fetal bovine serum-RPMI. Subsequently, contaminated red blood cells were lysed by ammonium chloride-based buffer before flow cytometric analysis.

\section{Statistical analysis}

The results are expressed as mean \pm standard deviation. The significance between two groups was determined using the two-sample independent $t$ test. $P<0.05$ was defined as significant. In terms of multiple comparisons, Bonferroni's test was used to correct the $P$ value for the $t$ test. The processing and statistical analysis of the data was performed using OriginPro 7.5 software (OriginPro, Inc., Northampton, MA, USA).

\section{Results}

Low dose of IGFBP1, IGFBP2, IGF2 and ANGPTL3 is enough to boost the ex vivo expansion of $\mathrm{CD} 34^{+} \mathrm{CD} 38^{-} \mathrm{CD} 90^{+}$ primitive progenitor cells

When cryopreserved UCB mononuclear cells were cultured on a BM-derived mesenchymal stromal cell layer with the standard cytokine cocktail $(100 \mathrm{ng} / \mathrm{ml} \mathrm{SCF}, 50$ $\mathrm{ng} / \mathrm{ml} \mathrm{FL}$ and $100 \mathrm{ng} / \mathrm{ml} \mathrm{TPO}$ ) plus individually varied doses of IGFBP1, IGFBP2, IGF2 and ANGPTL3, the highest expansion of $\mathrm{CD} 34^{+} \mathrm{CD} 38^{-} \mathrm{CD} 90^{+}$primitive progenitor appeared at a low dose of $20 \mathrm{ng} / \mathrm{ml}$ for IGFBP1, IGFBP2, IGF2 and ANGPTL3 (concentrations of 0, 20, 50, 100 and $200 \mathrm{ng} / \mathrm{ml}$ were studied) (Figure 1D). The expansion of total nucleated cells, CD34 ${ }^{+}$cells and granulocyte-macrophage colony-forming units decreased with increasing dose of cytokine (Figure 1A,B,C). Based on the above
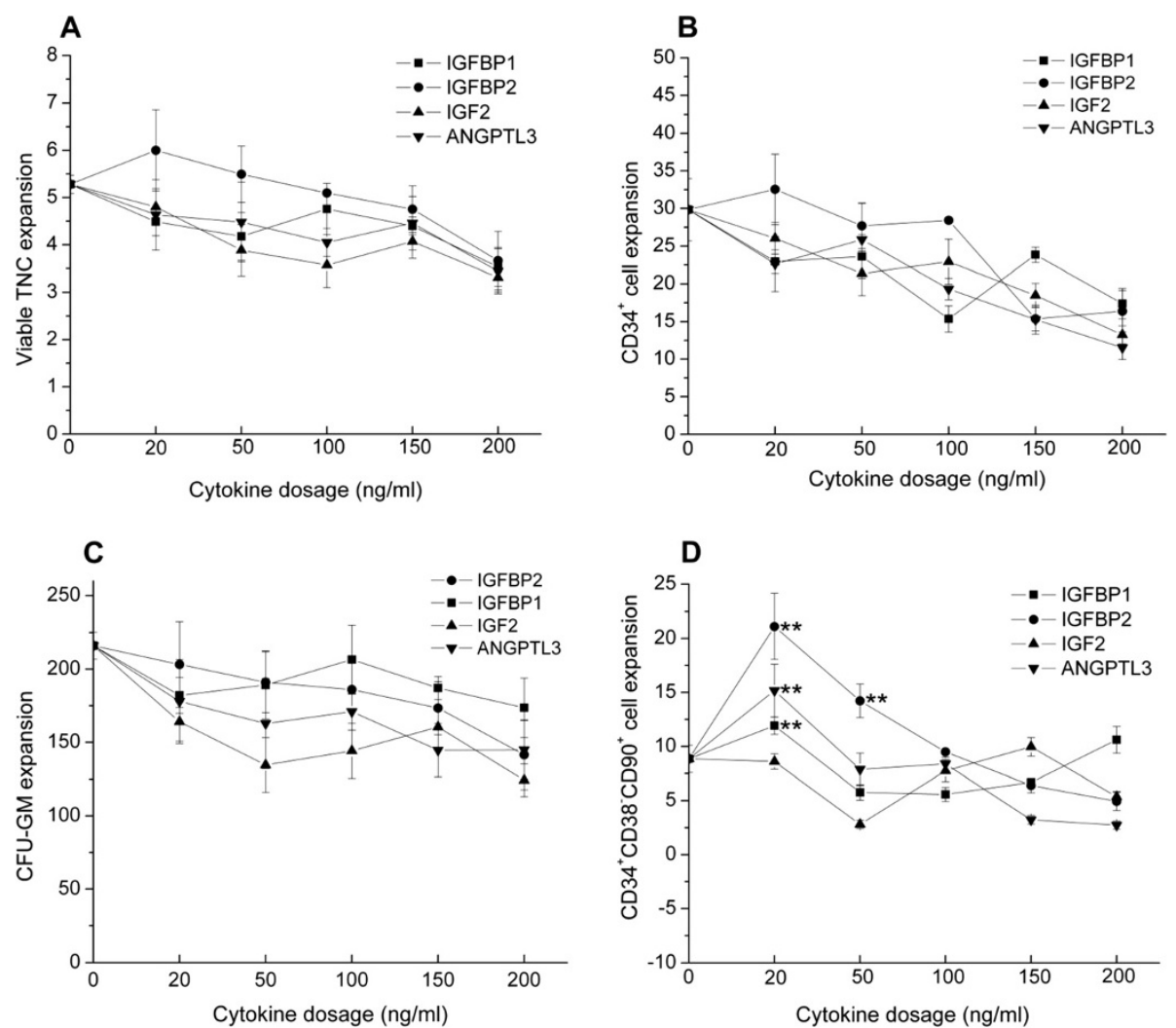

Figure 1 IGFBP1, IGFBP2, IGF2 and ANGPTL3 stimulate the ex vivo expansion of $\mathrm{CD} 34^{+} \mathrm{CD} 38^{-} \mathrm{CD} 90^{+}$primitive progenitors at low dose. Post-thaw umbilical cord blood cells $\left(4 \times 10^{5} \mathrm{cell} / \mathrm{s} / \mathrm{ml}\right)$ were suspended in serum-free Stemspan ${ }^{\oplus}$ media (Stemcell technologies, vancouver, BC, Canada) supplied with different doses of indicated cytokines in the range 0 to $200 \mathrm{ng} / \mathrm{ml}$ and standard cytokine combinations of $100 \mathrm{ng} / \mathrm{ml}$ stem cell factor, $50 \mathrm{ng} / \mathrm{ml}$ FLT3 ligand and $100 \mathrm{ng} / \mathrm{ml}$ thrombopoietin, inoculated on a passage 3 to 5 bone marrow-derived mesenchymal stromal cell layer in a 24-well plate and cultured for 12 days. (A) Expansion of viable total nucleated cells (TNCs). (B) Expansion of CD34 ${ }^{+}$cells. (C) Expansion of granulocyte-macrophage colony-forming units (CFU-GM). (D) Expansion of CD $34^{+} \mathrm{CD} 38^{-} \mathrm{CD} 90^{+}$cells. Results expressed as mean \pm standard deviation. For each novel cytokine, a $t$ test was performed between the variant cytokine dosage group and baseline (standard cytokine combination). ${ }^{*} P<0.01$. ANGPTL, angiopoietin-like protein; IGF, insulin-like growth factor; IGFBP, insulin-like growth factor binding protein. 
result, the range of cytokine dose was further narrowed to 0 to $50 \mathrm{ng} / \mathrm{ml}$. The optimal cytokine dose was determined at $20 \mathrm{ng} / \mathrm{ml} \mathrm{IGFBP2}$ and ANGPTL3, $15 \mathrm{ng} / \mathrm{ml}$ IGFBP1 and $10 \mathrm{ng} / \mathrm{ml}$ IGF2 when maximal expansion of $\mathrm{CD} 34^{+} \mathrm{CD} 38^{-} \mathrm{CD} 90^{+}$primitive progenitor was reached, which was significantly higher than standard cytokine combination $(P=0.01)$ (Figure 2D). Similarly, these four novel cytokines did not contribute to the expansion of total nucleated cells, CD $34^{+}$cells and granulocyte-macrophage colony-forming units (Figure 2A,B,C).

\section{'SCF + TPO + FL + IGFBP1 + IGFBP2 + ANGPTL3' is the optimal combination to enhance ex vivo expansion of CD $34^{+} \mathrm{CD} 38^{-} \mathrm{CD}^{+} 0^{+}$primitive progenitor cells}

To determine the optimal cytokine combination, complete permutation was carried out after establishing the optimal dose of each cytokine. The combination 'SCF + TPO + FL + IGFBP1 + IGFBP2 + ANGPTL3' had superior expansion of $\mathrm{CD} 4^{+} \mathrm{CD} 38^{-} \mathrm{CD}^{+} 0^{+}$primitive progenitor $(16.3 \pm 3.9$-fold versus $7.5 \pm 1.9$-fold with standard cytokine cocktail) compared with all other combinations (Figure 3D). Similarly, despite promoting expansion of $\mathrm{CD}_{3} 4^{+} \mathrm{CD} 38^{-} \mathrm{CD} 90^{+}$ primitive cells, there was no further enhancement of expansion of total cells and general progenitors compared with control (Figure $3 \mathrm{~A}, \mathrm{~B}, \mathrm{C}$ ), suggesting that this cytokine cocktail only enhanced the earlier progenitors. Hence, representative cytokine cocktails of 'SCF + TPO + FL', 'SCF + TPO + FL + IGFBP2', 'SCF + TPO + FL + IGFBP2 + IGF2 + ANGPTL3' and 'SCF + TPO + FL + IGFBP1 + IGFBP2 + ANGPTL3' were chosen for further validation in NSG mice.

\section{Equivalent human cell engraftment and multi-lineage reconstitution profile between unexpanded and expanded umbilical cord blood}

NSG repopulation assays were performed to determine whether the ex vivo expanded cells were capable of long-term hematopoiesis. Thus, $5 \times 10^{5}$ and $1 \times 10^{6}$ unexpanded cells and $1 \times 10^{6}$ and $2 \times 10^{6}$ expanded cells with four cytokine combinations of 'SCF + TPO + FL', 'SCF + TPO + FL + IGFBP2', 'SCF + TPO + FL + IGFBP2 +
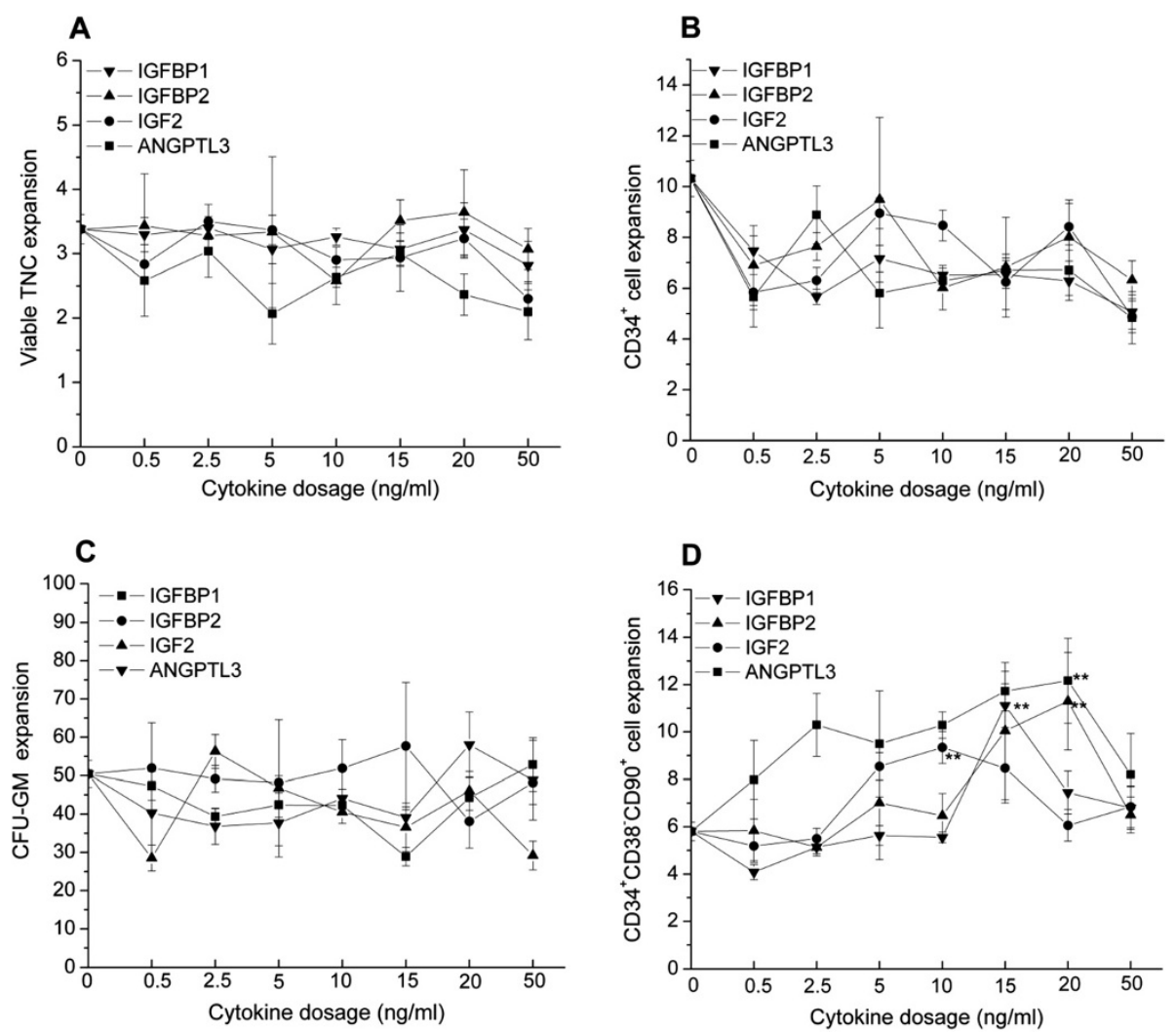

Figure 2 Optimal dose of IGFBP1, IGFBP2, IGF2 and ANGPTL3 was established from 10 to $20 \mathrm{ng} / \mathrm{ml}$. Post-thaw umbilical cord blood cells $\left(4 \times 10^{5}\right.$ cells $\left./ \mathrm{ml}\right)$ were suspended in serum-free Stemspan ${ }^{\oplus}$ media (Stemcell technologies, vancouver, BC, Canada) supplied with different doses of indicated cytokines in the range 0 to $50 \mathrm{ng} / \mathrm{ml}$ and standard cytokine combinations of $100 \mathrm{ng} / \mathrm{ml}$ stem cell factor, $50 \mathrm{ng} / \mathrm{ml} \mathrm{FLT3} \mathrm{ligand} \mathrm{and}$ $100 \mathrm{ng} / \mathrm{ml}$ thrombopoietin, inoculated on a passage 3 to 5 bone marrow-derived mesenchymal stromal cell layer in a 24-well plate and cultured for 12 days. (A) Expansion of viable total nucleated cells (TNCS). (B) Expansion of CD34+ cells. (C) Expansion of granulocyte-macrophage colony-forming units (CFU-GM). (D) Expansion of $\mathrm{CD} 34^{+} \mathrm{CD} 38^{-} \mathrm{CD} 90^{+}$cells. Results expressed as mean \pm standard deviation. For each novel cytokine, the $t$ test was performed between the variant cytokine dosage group and baseline (standard cytokine combination). ${ }^{* *} P<0.01$. ANGPTL, angiopoietin-like protein; IGF, insulin-like growth factor; IGFBP, insulin-like growth factor binding protein. 

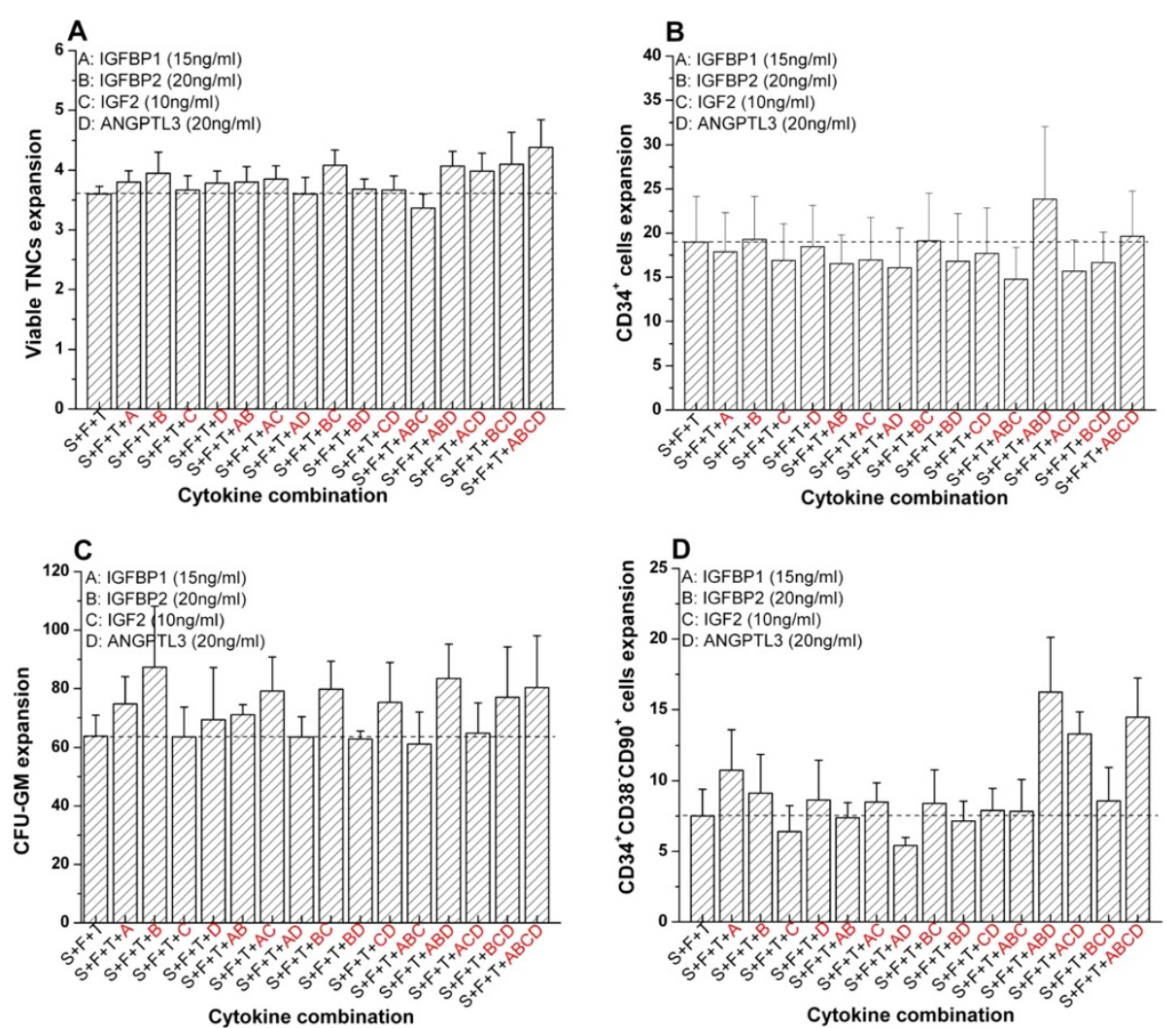

Figure 3 'SCF + TPO + FL + IGFBP1 + IGFBP2 + ANGPTL3' is the optimal cytokine combination to enhance ex vivo expansion of CD34 ${ }^{+} \mathrm{CD} 38^{-} \mathrm{CD} 90^{+}$primitive progenitor cells. Post-thaw umbilical cord blood cells $\left(4 \times 10^{5} \mathrm{cell} / \mathrm{s} / \mathrm{ml}\right)$ were suspended in serum-free Stemspan ${ }^{\oplus}$ media (Stemcell technologies, vancouver, BC, Canada) supplied with different cytokine combinations with optimal doses and standard cytokine combinations of $100 \mathrm{ng} / \mathrm{ml}$ stem cell factor (S), $50 \mathrm{ng} / \mathrm{ml} \mathrm{FLT3} \mathrm{ligand} \mathrm{(F)} \mathrm{and} 100 \mathrm{ng} / \mathrm{ml}$ thrombopoietin (T), inoculated on a passage 3 to 5 bone marrow-derived mesenchymal stromal cell layer in a 24-well plate and cultured for 12 days. Here, the optimal dose of IGFBP1 (A), IGFBP2 (B), IGF2 (C) and ANGPTL3 (D) was $15 \mathrm{ng} / \mathrm{ml}, 20 \mathrm{ng} / \mathrm{ml}, 10 \mathrm{ng} / \mathrm{ml}$ and $20 \mathrm{ng} / \mathrm{ml}$ respectively. (A) Expansion of viable total nucleated cells (TNCs). (B) Expansion of $\mathrm{CD}_{4}{ }^{+}$cells. (C) Expansion of granulocyte-macrophage colony-forming units (CFU-GM). (D) Expansion of CD34 ${ }^{+} \mathrm{CD} 38^{-} \mathrm{CD} 90^{+}$cells. Results expressed as mean \pm standard error (cord blood unit number, $n=6$ ). ANGPTL, angiopoietin-like protein; IGF, insulin-like growth factor; IGFBP, insulin-like growth factor binding protein.

IGF2 + ANGPTL3' and 'SCF + TPO + FL + IGFBP1 + IGFBP2 + ANGPTL3' were transplanted to irradiated NSG mice. The results did not demonstrate any significant difference in the human cell long-term engraftment when the mice received $\mathrm{UCB}$ expanded with cytokine combinations of 'SCF + TPO + FL', 'SCF + TPO + FL + IGFBP2,'SCF + TPO + $\mathrm{FL}+\mathrm{IGFBP} 2+\mathrm{IGF} 2+\mathrm{ANGPTL3}$ ' and 'SCF + TPO + FL + IGFBP1 + IGFBP2 + ANGPTL3' compared with unexpanded UCB $(P<0.05$; Figure $4 \mathrm{~A})$. This means that the stem cell repopulation properties were not lost during the ex vivo expansion. In addition, representative mice that received $2 \times 10^{6}$ expanded cells cultured with the cytokine combination 'SCF + FL + TPO + IGFBP1 + IGFBP2 + ANGPTL3' displayed an equivalent multi-lineage differentiation capacity of primitive human cells (CD34 $\left.{ }^{+}, 0.26 \pm 0.11 \%\right)$, myeloid cells $\left(\mathrm{CD} 45^{+} \mathrm{CD} 71^{+}, 0.2 \pm 0.08 \%\right.$; CD $15 / 66 \mathrm{~b}^{+}, 0.16 \pm$ $0.07 \%)$, B-lymphoid cells $\left(\mathrm{CD} 19 / 20^{+}, 0.87 \pm 0.56 \%\right)$ and T-lymphoid cells $\left(\mathrm{CD}^{+}, 0.01 \pm 0.001 \%\right)$ to mice that received $0.5 \times 10^{6}$ unexpanded cells of $0.36 \pm 0.23 \%, 0.52 \pm$ $0.32 \%, 0.47 \pm 0.36 \%, 0.47 \pm 0.27 \%$ and $2.15 \pm 0.82 \% \quad(P=$ $0.81, P=0.58, P=0.64, P=0.50$ and $P=0.15$; Figure $4 \mathrm{~B})$. For T-lymphoid cell differentiation, even though there was no significant difference between expanded units and unexpanded units from statistical analysis, from direct observation we could say that the unexpanded unit was better than the expanded unit.

Phenotypic marker of $\mathrm{CD} 34^{+} \mathrm{CD} 38^{-} \mathrm{CD} 90^{+}$can be used as a hematopoietic stem cell ex vivo detecting marker

After 4 months of transplantation, the limiting dilution assay showed that the competitive repopulating unit (CRU) was $1 / 1.53 \times 10^{6}, 1 / 1.6 \times 10^{6}, 1 / 1.4 \times 10^{6}$ and $1 /$ $1.2 \times 10^{6}$ in the expanded cells cultured with cytokine combinations of 'SCF + TPO + FL', 'SCF + TPO + FL + IGFBP2', 'SCF + TPO + FL + IGFBP2 + IGF2 + ANGPTL3' and 'SCF + TPO + FL + IGFBP1 + IGFBP2 + ANGPTL3' com- 

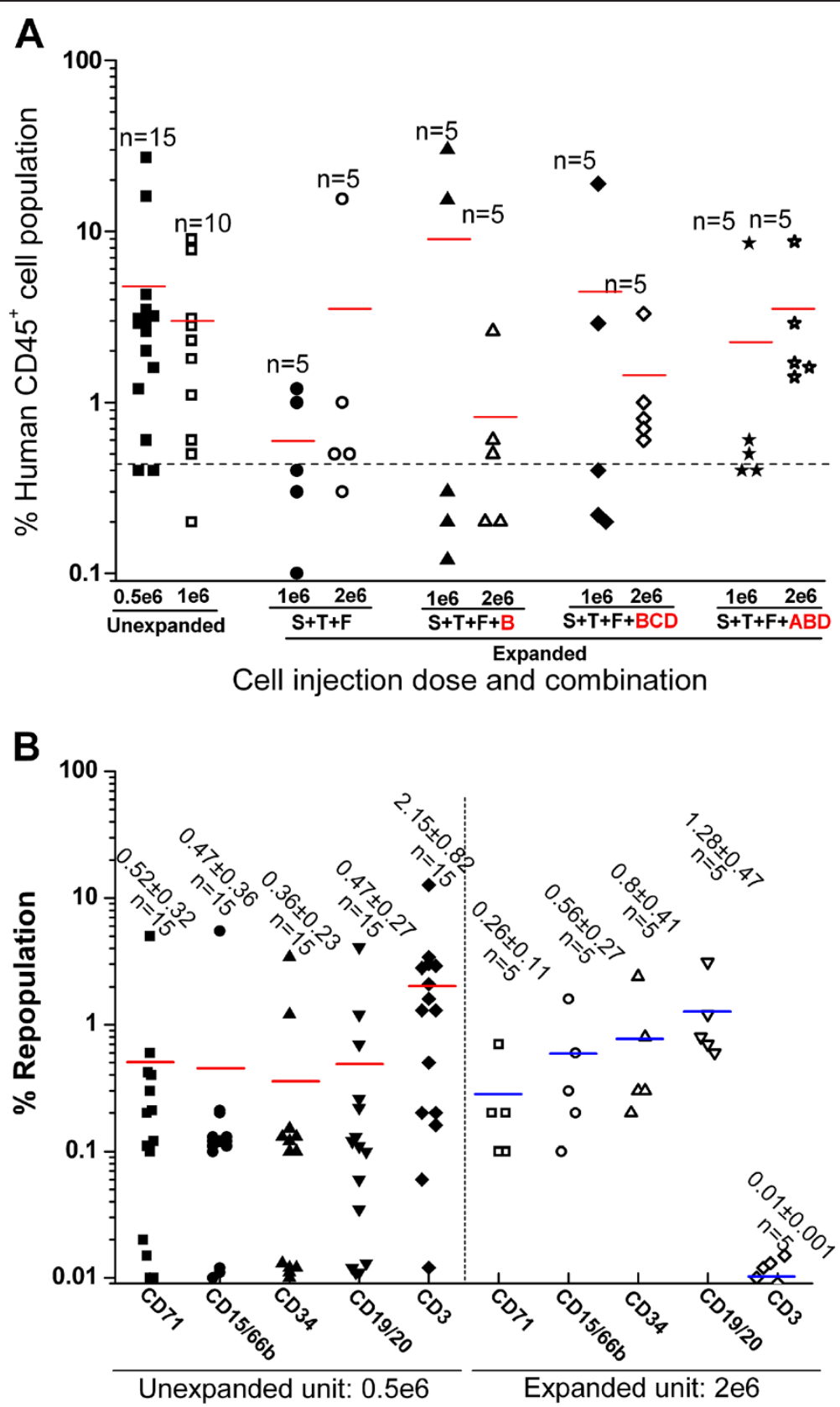

Figure 4 Human cell engraftment and multi-lineage reconstitution profile. (A) Amount of human chimerism in the bone marrow of NOD/ SCID-IL2RY ${ }^{-1-}$ mice that received a transplant of $5 \times 10^{5}$ and $1 \times 10^{6}$ unexpanded human mononuclear cord blood cells and $1 \times 10^{6}$ and $2 \times 10^{6}$ expanded progeny cells. Each symbol represents the engraftment of a single mouse that underwent transplantation assayed at 4 months post transplantation. (B) Summary of multi-lineage reconstitution from mice bone marrow transplanted $5 \times 10^{5}$ unexpanded cells in lane 1 and transplanted $2 \times 10^{6}$ expanded cells with the cytokine combination ' $S+F+T+A B D$ ' in lane 10 of (A). S, stem cell factor; F, FLT3 ligand; T, thrombopoietin. A, IGFBP1; B, IGFBP2; C, IGF2; D, ANGPTL3. ANGPTL, angiopoietin-like protein; IGF, insulin-like growth factor; IGFBP, insulin-like growth factor binding protein.

pared with $1 / 6.1 \times 10^{5}$ in the unexpanded cells when $P<0.05$ (Figure 5A). There was thus 4.4-fold, 4.3-fold, 4.5-fold and 6.4-fold in vivo expansion of long-term HSCs based on calculation according to the viable total nucleated cell expansion (Figure 5B, lane 1). There was $6.4 \pm 0.2$-fold, $6.0 \pm 0.1$-fold, $6.8 \pm 0.2$-fold and $8.8 \pm 0.5$ - fold ex vivo expansion of $\mathrm{CD} 34^{+} \mathrm{CD} 38^{-} \mathrm{CD} 90^{+}$cells according to these four cytokine combinations (Figure 5B, lane 4). Strangely, there is always a close ratio of $69.8 \pm$ $2.9 \%$ between in vivo expansion of the CRU and ex vivo expansion of $\mathrm{CD} 34^{+} \mathrm{CD} 38^{-} \mathrm{CD} 90^{+}$cells in different cytokine combinations (Figure 5C). The excellent correlation 

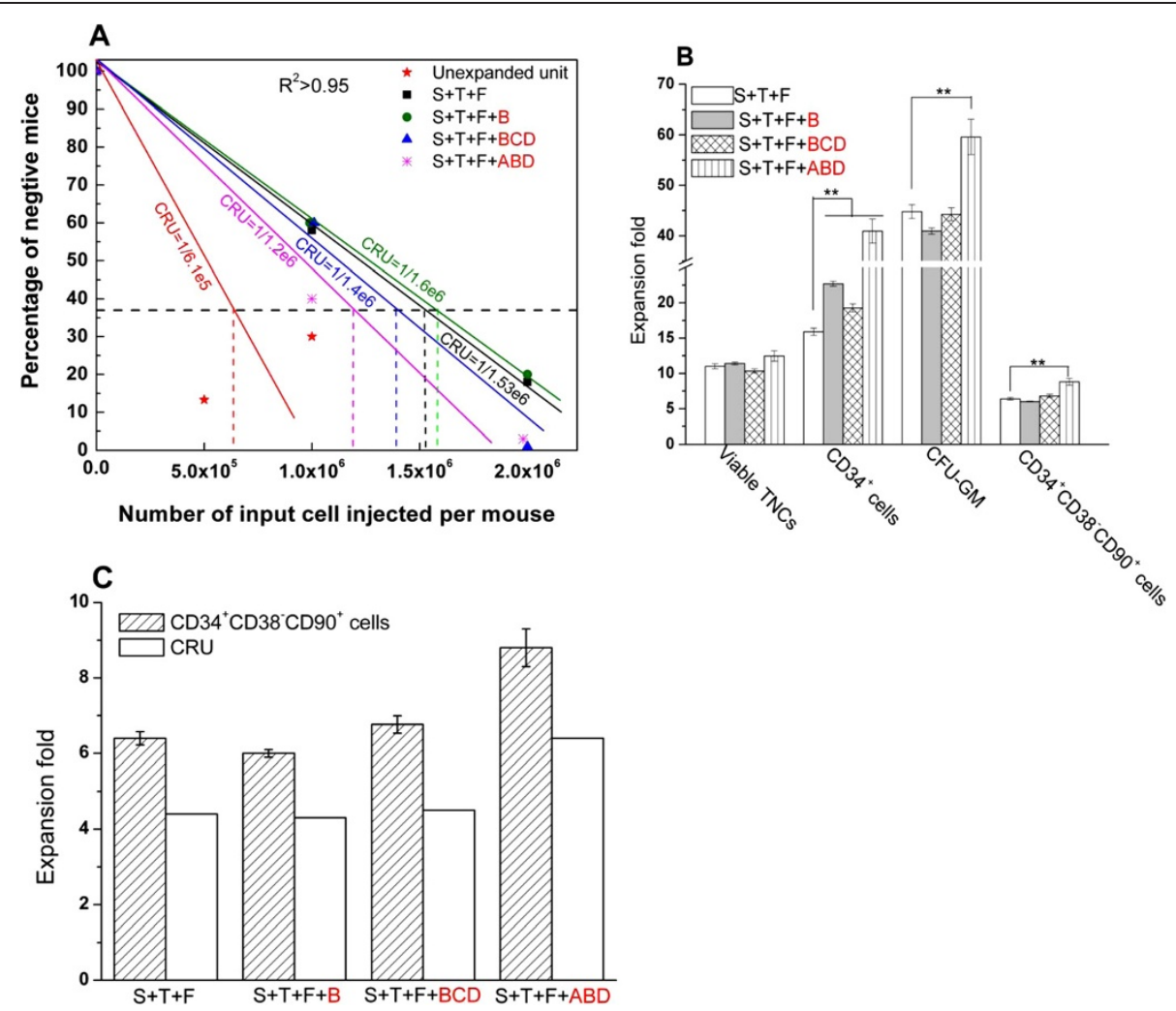

Figure 5 Cytokine combination of 'SCF + TPO + FL + IGFBP1 + IGFBP2 + ANGPTL3' stimulates highest ex vivo expansion of primitive progenitors as assayed in NOD/SCID-IL2R ${ }^{-1}$ mice. (A) Limiting dilution assay for the unexpanded and expanded cells. Negative engraftment was defined by less than $0.5 \%$ of human $C D 45^{+}$cell engraftment in mice bone marrow $(P<0.05)$. (B) Ex vivo expansion of umbilical cord blood (UCB) cells. Post-thaw UCB cells $\left(4 \times 10^{5}\right.$ cells $\left./ \mathrm{ml}\right)$ were suspended in serum-free Stemspan ${ }^{\oplus}$ media (Stemcell technologies, vancouver, BC, Canada) supplied with cytokine combinations of 'S $+T+F^{\prime}$ ', $S+T+F+B^{\prime}, ' S+T+F+B C D$ ' and 'S $+T+F+A B D$ ' respectively, inoculated on a passage 3 to 5 bone marrow-derived mesenchymal stromal cell layer in a $T_{175}$ flask and cultured for 12 days. Here, the concentration of stem cell factor (S), FLT3 ligand (F), thrombopoietin (T), IGFBP1 (A), IGFBP2 (B), IGF2 (C) and ANGPTL3 (D) was 100 ng/ml, $50 \mathrm{ng} / \mathrm{ml}, 100$ ng/ml, 15 ng/ml, 20 ng/ml, 10 ng/ml and $20 \mathrm{ng} / \mathrm{ml}$ respectively. (C) Correlation of in vivo competitive repopulating unit (CRU) functional assay and ex vivo CD $34^{+} \mathrm{CD} 38^{-} \mathrm{CD} 90^{+}$cell surface marker. Results expressed as mean \pm standard deviation. For multiple comparisons, Bonferroni's test was used to correct the $P$ value for the $t$ test. $P<0.05 \rightarrow P_{\text {corrected }}<0.017$ and $P<0.01 \rightarrow P_{\text {corrected }}<0.003$ when $n=3$. ${ }^{*} P<0.05$, ${ }^{* *} P<0.01$. ANGPTL, angiopoietin-like protein; CFU-GM, granulocyte-macrophage colony-forming units; IGF, insulin-like growth factor; IGFBP, insulin-like growth factor binding protein; TNC, total nucleated cell.

between the HSC ex vivo surface marker of $\mathrm{CD}_{3} 4^{+}$ $\mathrm{CD} 38^{-} \mathrm{CD} 90^{+}$and the in vivo $\mathrm{CRU}$ functional assay indicate that phenotypic combination of $\mathrm{CD} 34^{+} \mathrm{CD} 38^{-} \mathrm{CD} 90^{+}$ can be used as an HSC ex vivo detecting biomarker.

\section{Discussion}

In this study, IGFBP1, IGFBP2, IGF2 and ANGPTL3 have been demonstrated to stimulate ex vivo expansion of $\mathrm{CD} 34^{+} \mathrm{CD} 38^{-} \mathrm{CD} 90^{+}$primitive progenitor at a low dose of $15 \mathrm{ng} / \mathrm{ml}$ IGFBP1, $10 \mathrm{ng} / \mathrm{ml}$ IGF2 and $20 \mathrm{ng} / \mathrm{ml}$ IGFBP2 and ANGPTL3. The optimal cytokine combination comprises IGFBP1, IGFBP2 and ANGPTL3 together with the standard cytokine cocktail of SCF, FL and TPO. In view of the excellent correlation between the HSC ex vivo surface marker of $\mathrm{CD} 34^{+} \mathrm{CD} 38^{-} \mathrm{CD} 90^{+}$ and the in vivo CRU functional assay, the $\mathrm{CD} 34^{+} \mathrm{CD} 38^{-}$
$\mathrm{CD} 90^{+}$phenotype can serve as an ex vivo surrogate surface marker for HSCs.

We showed that IGFBP1, IGFBP2, IGF2 and ANGPTL3 could stimulate the ex vivo expansion of HSCs or primitive progenitors rather than common progenitors and total cells, in agreement with recent reports $[4,6,7,9,10]$. However, this stimulation had a negative correlation to cytokine dose, where a high dose of cytokine induced low expansion of primitive progenitors. In fact, the optimal cytokine dose appeared at the lower range of 10 to $20 \mathrm{ng} / \mathrm{ml}$. Compared with 100 to $500 \mathrm{ng} / \mathrm{ml}$ high-dose cytokine usage, this 10 to $20 \mathrm{ng} / \mathrm{ml}$ low dose will help to dramatically reduce the cost in clinical applications.

In addition, our data also showed that an expanded unit with the established optimal cytokine cocktail of 'SCF + TPO + FL + IGFBP1 + IGFBP2 + ANGPTL3' had the capacity of multi-lineage reconstitution except for 
T-lymphoid cells. Even though the statistical analysis showed that there was no significant difference on T-lymphoid cell differentiation between expanded units and unexpanded units, T-lymphoid reconstitution capacity from the unexpanded unit was better than from the expanded unit by direct observation. The explanation for this phenomenon could be due to the cytokine cocktail used in ex vivo expansion to drive cultured cells to expand and differentiate into the myeloid lineage rather than the T-lymphoid lineage (data not shown). This defect can be overcome by double cord blood transplantation with one expanded unit and one unexpanded unit as demonstrated in our previous publication $[15,16]$.

From the limiting dilution assay, we know that only about $70 \%$ of expanded $\mathrm{CD} 34^{+} \mathrm{CD} 38^{-} \mathrm{CD} 90^{+}$primitive progenitors will reconstitute in NSG mice. What then happens to that $30 \%$ of expanded $\mathrm{CD} 34^{+} \mathrm{CD} 38^{-} \mathrm{CD} 90^{+}$ primitive progenitors? We postulate two possibilities; the first is that $30 \%$ of expanded $\mathrm{CD} 34^{+} \mathrm{CD} 38^{-} \mathrm{CD} 90^{+}$primitive progenitors lose their in vivo reconstitution capacity during ex vivo expansion even though they express the biomarker phenotypically, while the second possibility could be that $70 \%$ of expanded $\mathrm{CD} 34^{+} \mathrm{CD} 38^{-} \mathrm{CD} 90^{+}$ primitive progenitors possess self-renewal, pluripotency and long-term reconstitution capacity, whereas only $30 \%$ of them have short-term hematopoietic reconstitution capacity.

\section{Conclusions}

IGFBP1, IGFBP2, IGF2 and ANGPTL3 can stimulate ex vivo expansion of $\mathrm{CD} 34^{+} \mathrm{CD} 38^{-} \mathrm{CD} 90^{+}$primitive progenitor at low dose with the optimal cytokine combination comprising IGFBP1, IGFBP2 and ANGPTL3 together with the standard cytokine cocktail of SCF, FL and TPO. The $\mathrm{CD} 34^{+} \mathrm{CD} 38^{-} \mathrm{CD} 90^{+}$phenotype can serve as a surrogate ex vivo surface marker for HSC detection due to consistency with the in vivo CRU functional assay.

\section{Abbreviations \\ ANGPTL: angiopoietin-like protein; BM: bone marrow; CRU: competitive repopulating unit; FL: FLT3 ligand; HSC: hematopoietic stem cell; IGFBP: insulin-like growth factor binding protein; IGF: insulin-like growth factor; NSG: nonobese diabetic/severe combined immunodeficiency interleukin 2 gamma chain null (NOD/SCID-IL2R ${ }^{-1-}$ ); SCF: stem cell factor; TPO: thrombopoietin; UCB: umbilical cord blood.}

\section{Competing interests}

The authors declare that they have no competing interests.

\section{Authors' contributions}

XF was involved in conception of the study, experimental design, data interpretation, and drafting and revising the manuscript. FPHG and JMLA helped to carry out the colony-forming assay, flow cytometric assay and animal sample acquisition, and drafted the manuscript. FWIL provided suggestions and helped to revise the manuscript. PPYC and SB participated in the study design, data analysis and interpretation. WYKH had full access to all of the data in the study and takes responsibility for the integrity of the data and the accuracy of the data analysis. All authors read and approved the final manuscript.

\section{Acknowledgements}

The authors thank Bryan and Zheng Lin, staff of SingHealth Experimental Medicine Centre, for help with mice work. This work was supported by a Cancer Syndicate Grant (grant number SCS-T0049) and a Central Grant (NMRC/CG/SGH/2010).

\section{Author details}

'Department of Clinical Research, Singapore General Hospital, 20 College Road, Academia Level 9, Discovery Tower, Singapore 169856, Singapore. ${ }^{2}$ Cancer \& Stem Cell Biology, Duke-NUS Graduate Medical School, College Road, Singapore 169857, Singapore. ${ }^{3}$ Department of Hematology, Singapore General Hospital, 20 College Road, Academia Level 3, Singapore 169856, Singapore.

Received: 31 October 2013 Revised: 29 November 2013

Accepted: 21 May 2014 Published: 30 May 2014

\section{References}

1. Noh YH, Yim YS, Kim DH, Lee MW, Kim DS, Kim HR, Lee SH, Chueh HW, Choi SJ, Oh WI, Yang YS, Jung HL, Yoo KH, Sung KW, Koo HH: Correlation between chemokines released from umbilical cord blood-derived mesenchymal stem cells and engraftment of hematopoietic stem cells in nonobese diabetic/severe combined immunodeficient (NOD/SCID) mice. Pediatr Hematol Oncol 2011, 28:682-690.

2. Chou S, Lodish HF: Fetal liver hepatic progenitors are supportive stromal cells for hematopoietic stem cells. Proc Natl Acad Sci USA 2010, 107:7799-7804.

3. Hofmann WK, Takeuchi S, Frantzen MA, Hoelzer D, Koeffler HP: Loss of genomic imprinting of insulin-like growth factor 2 is strongly associated with cellular proliferation in normal hematopoietic cells. Exp Hematol 2002, 30:318-323.

4. Celebi B, Mantovani D, Pineault N: Insulin-like growth factor binding protein-2 and neurotrophin 3 synergize together to promote the expansion of hematopoietic cells ex vivo. Cytokine 2012, 58:327-331

5. Drake AC, Khoury M, Leskov I, lliopoulou BP, Fragoso M, Lodish H, Chen J: Human $\mathrm{CD} 34^{+} \mathrm{CD} 133^{+}$hematopoietic stem cells cultured with growth factors including Angpt 5 efficiently engraft adult NOD-SCID II rgamma $^{-/-}$ (NSG) mice. PLoS One 2011, 6:e18382.

6. Khoury M, Drake A, Chen Q, Dong D, Leskov I, Fragoso MF, Li Y, lliopoulou BP, Hwang W, Lodish HF, Chen J: Mesenchymal stem cells secreting angiopoietin-like-5 support efficient expansion of human hematopoietic stem cells without compromising their repopulating potential. Stem Cells Dev 2011, 20:1371-1381

7. Huynh H, lizuka S, Kaba M, Kirak O, Zheng J, Lodish HF, Zhang CC: Insulin-like growth factor-binding protein 2 secreted by a tumorigenic cell line supports ex vivo expansion of mouse hematopoietic stem cells. Stem Cells 2008, 26:1628-1635.

8. Lin TC, Yen JM, Gong KB, Hsu TT, Chen LR: IGF-1/IGFBP-1 increases blastocyst formation and total blastocyst cell number in mouse embryo culture and facilitates the establishment of a stem-cell line. BMC Cell Biol 2003, 4:14.

9. Zhang CC, Kaba M, lizuka S, Huynh H, Lodish HF: Angiopoietin-like 5 and IGFBP2 stimulate ex vivo expansion of human cord blood hematopoietic stem cells as assayed by NOD/SCID transplantation. Blood 2008, 111:3415-3423.

10. Zhang CC, Kaba M, Ge G, Xie K, Tong W, Hug C, Lodish HF: Angiopoietin-like proteins stimulate ex vivo expansion of hematopoietic stem cells. Nat Med 2006, 12:240-245.

11. Huynh $H$, Zheng J, Umikawa M, Zhang C, Silvany R, lizuka S, Holzenberger M, Zhang W, Zhang CC: IGF binding protein 2 supports the survival and cycling of hematopoietic stem cells. Blood 2011, 118:3236-3243.

12. Bartling B, Koch A, Simm A, Scheubel R, Silber RE, Santos AN: Insulin-like growth factor binding proteins- 2 and -4 enhance the migration of human $\mathrm{CD}^{-} 4^{-} / \mathrm{CD} 133^{+}$hematopoietic stem and progenitor cells. Int J Mol Med 2010, 25:89-96.

13. Broxmeyer HE, Srour EF, Cooper S, Wallace CT, Hangoc G, Youn BS: Angiopoietin-like-2 and -3 act through their coiled-coil domains to enhance survival and replating capacity of human cord blood hematopoietic progenitors. Blood Cells Mol Dis 2012, 48:25-29.

14. Zheng J, Huynh H, Umikawa M, Silvany R, Zhang CC: Angiopoietin-like protein 3 supports the activity of hematopoietic stem cells in the bone marrow niche. Blood 2011, 117:470-479. 
15. Fan X, Gay FP, Ong SY, Ang JM, Chu PP, Bari S, Lim TK, Hwang WY: Mesenchymal stromal cell supported umbilical cord blood ex vivo expansion enhances regulatory $T$ cells and reduces graft versus host disease. Cytotherapy 2013, 15:610-619.

16. Ong LM, Fan X, Chu PP, Gay FP, Bari S, Ang JM, Li Z, Chen J, Lim SK, Bunte RM, Hwang WY: Cotransplantation of ex vivo expanded and unexpanded cord blood units in immunodeficient mice using insulin growth factor binding protein-2-augmented mesenchymal cell cocultures. Biol Blood Marrow Transplant 2012, 18:674-682.

doi: $10.1186 /$ scrt460

Cite this article as: Fan et al:: Low-dose insulin-like growth factor

binding proteins 1 and 2 and angiopoietin-like protein 3 coordinately stimulate ex vivo expansion of human umbilical cord blood

hematopoietic stem cells as assayed in NOD/SCID gamma null mice.

Stem Cell Research \& Therapy 2014 5:71.

\section{Submit your next manuscript to BioMed Central and take full advantage of:}

- Convenient online submission

- Thorough peer review

- No space constraints or color figure charges

- Immediate publication on acceptance

- Inclusion in PubMed, CAS, Scopus and Google Scholar

- Research which is freely available for redistribution 